\title{
The Translation of Metaphor from the Novel Beastly into Beastly, Beauty and the Beast Abad 21
}

\author{
Ni Nyoman Ayu Widyari ${ }^{1}$, Ida Bagus Putra Yadnya ${ }^{2}$, Ni Luh Nyoman Seri Malini ${ }^{3}$ \\ ${ }^{1}$ Magister of Linguistics, Translation Studies \\ Udayana University \\ Denpasar, Bali - Indonesia \\ Email: ayuwidya06@gmail.com \\ ${ }^{2}$ Magister of Linguistics, Translation Studies \\ Udayana University \\ Denpasar, Bali - Indonesia \\ Email: putra_yadnya@unud.ac.id \\ ${ }^{3}$ Magister of Linguistics, Translation Studies \\ Udayana University \\ Denpasar, Bali - Indonesia \\ Email: seri.malini@unud.ac.id
}

\begin{abstract}
The translation is a written medium and useful connection to communicate with other people in a different language, culture, and background. Figurative language is widely used in any form of communication, such as in daily conversations, advertisements, articles in newspapers, novels, poems, etc. Figurative language often provides more effective means of saying what can be meant than a direct statement. This writing is aimed at finding out the types of metaphors in translating the novel of Beastly based on the theory of Kovecses. The analysis was presented in the form of words and sentences. The result of this study showed that the use of a structural metaphor was mostly used in this study based on the data in the novel Beastly. The structural metaphor occurred as the source domain provides a relatively rich knowledge structure for the target or language concept.
\end{abstract}

Keywords: Figurative language, Metaphor, Structural metaphor.

\section{INTRODUCTION}

Translation has already become the focus of the problem when the object of the translation is a work of art such as a novel. The way to show the idea of the source language is a complex problem. In this case, we can say that the translator must be able to show the idea of original translation which was from the source language into target language which contains the same idea in the language where the product is marketed. The translation is a written medium and useful connection to communicate with other people in a different language, culture, and background. By the existence of translation, it can help people to share any perspective of this world. People can share information, knowledge, ideas, and lots of things. There are many differences in both source language (SL) and target language (TL) such as structure, culture, and style. Therefore, translation is very useful for people who do not have a good ability in understanding SL, so they need help to translate it into the TL. Translators should understand very well and be knowledgeable about the idea of original work which includes the source language, culture, and also where the novel is created. Besides, the translator must know the common knowledge about the culture of the target language. In translating a text, a translator should convey the message of the source language into the target language. Hatim and Mason (1997: 1), states that the translator both a receiver and a producer. While the translator's task is to read and to understand a written text (source text) and then to transfer the meaning to the TL in a written form. While the other explanation is added by Catford (1984: 12) that states the goal of a translator is to keep the meaning of the translation to be constant. Translators do not just transfer each word in the source language into the target language, but good translators must skillful in translating the SL into TL without changing the purpose and message in TL. This is done by going from the form of the first language to the form of a second language by way of semantic structure. It is meaning which is being transferred and must be held constant. From doing 
the translation of metaphor, a writer of a novel invites readers to think about something other than the written words in it and also gives more understanding to the readers about the content of novels.

In this study, the first finding was pointed to the types of metaphors by Kovecses. According to Kovecses (2010: 37), there are three kinds of metaphors, namely structural metaphors, ontological metaphors, and orientational metaphors. Some metaphors are shared across very different cultures and may perhaps be considered universal, whereas others are closely connected and limited to the society in which they are used. Such culture-specific metaphors can present a dilemma to the translator, who wishes to remain as true as possible to the source text (ST) without compromising the authenticity of target language (TL) use.

The second finding in this study is the translation quality of the data source. This theory is based on Nababan theory, however, some statements and results were supported by the data itself and translation studies. In researching quality, questionnaires were needed. Some correspondents' comments and respond supported this study to obtain the result of translation quality.

\section{RESEARCH METHOD}

In this research, there are some steps to be conducted and relates to the methodology for this study, library research was used. It can be divided into three following aspects, they are: data source was taken from the novel entitled "Beastly" by Alex Flinn, method and technique of collecting data of the study using documentation technique, and method and technique of analyzing data of this study using the qualitative method to analyze the types of metaphor based on theory. This study used a comparative study, one method to reveal the specific nature of a too well-known object is to compare it to other cases or specimens from another context. The metaphor data in the novel from both languages were listed and classified based on their forms. The data were identified based on their forms, and their meanings analyzed in connection to the content of the novel. The use of symbols, pictures, tables, and notes were done in this study. The analysis was presented descriptively in the form of words and sentences included metaphor for the way to identify and classify the types of the metaphor. Then next to the second problem to identify the translation quality of the data in the novel, there can be found that the questionnaire was useful to get the results. The researcher analyzes translation quality refers to Nababan"s Theory as a grand theory and found that there are accuracy, acceptability, and readability aspects. From the response of the correspondent on the questionnaire, the statement of quality could be accepted. The correspondent should be able to master both languages before answering the answers.

\section{RESULTS AND DISCUSSION}

According to Kovecses (2010: 4), metaphor is defined as understanding one conceptual domain in terms of another conceptual domain. Examples of this include when talking and thinking about life in terms of journeys, about arguments in terms of war, about love also in terms of journeys, about theories in terms of building, about ideas in terms of food, about social organizations in terms of plants, and many others. Larson (1998:275) stated that to analyze metaphors, it was very helpful to write out the prepositions which were basic to the comparison. The topic (the thing being talked about), the image (what was being compared to), and the point of similarity (found in the comments of both of the prepositions) involved, should be included. When these have been identified, adequate translation can be made into a second language.

While Newmark in A Textbook of Translation (1988:104) defined metaphor as any figurative expression: it can be a word used in its figurative sense in a figurative sense call forth); personification of abstract concepts etc. Structurally metaphors are divided into simple that is represented by a single lexical unit, and compound or common, which may be represented by a word-group, a phrase, a sentence, or a whole text. A metaphor is a way of expressing an idea, feeling, emotional, even influence someone's mind by comparing it with something else that has a similar characteristic. According to Kovecses (2010: 37 ), there are three kinds of metaphors, namely structural metaphors, ontological metaphors, and orientational metaphors. It is an expression in which word and phrase and the concept represented stands figuratively for another word or phrase and its concept. Referring to the concept of metaphor which this study focused on, there are main concepts used in this study which are based on Kovecses theory.

In this study, the source of data is from the novel Beastly, originally from English into Indonesia. Beastly is a 2007 novel by Alex Flinn. It is a retelling of the fairytale Beauty and the Beast set in modernday New York City from the view of the beast. Flinn researched many versions of the Beauty and the Beast story to write her book. Many of these are playfully alluded to in portions of the book, particularly the chat room transcripts in which the character of Kyle talks to other teens who have been transformed into creatures. Kyle Kingsbury is rich, handsome, and popular, is also selfish, shallow, and cruel. He plays a mean "practical joke" on an outcast girl in his class. The girl is a witch named Kendra in disguise. The witch then curses him for his cruelty. 
He is turned into a beast; however, because he performed a small act of kindness shortly before his transformation when he gave an unwanted rose corsage to a girl working a ticket booth, she gives him two years to break the spell, or remain a beast forever. The only way he can turn back to normal is if he truly loves a girl and gets her to love him in return, proving the love with a kiss. Kendra later offers Kyle further aid by giving him a magic mirror that shows him whomever he wishes to see. He is locked in a mansion-like apartment by his equally shallow, image-obsessed father. His only company is his housekeeper, Magda, and, at his request, a blind tutor named Will. Kyle finds solace in a greenhouse for roses that he tends himself. After a year of being in this state, and trying and failing to find love, Kyle changes his name to Adrian, meaning "the dark one", to reflect his feelings of being a completely different person from the conceited, materialistic boy he used to be. When a robber stumbles into his garden Adrian offers him a deal; he will not report the robber to the police if the robber brings Adrian his daughter, Linda. She is Adrian's last chance to break the spell before his two years are up.

Adrian realizes that Linda is the same girl to whom he gave the rose corsage. He fixes up a room for her, leaving roses and books for her to amuse herself with. When she arrives, she at first wants nothing to do with him as she feels he kidnapped her. As time passes, she slowly warms up to him and he finds himself falling in love with her. The two begin to have tutoring sessions together and during winter they go to a lodge. Shortly before the last year is up, Linda wishes to see her father once more. Adrian lets her see him with the magic mirror and she finds that he has become sick through drug use. Adrian quickly lets her go to him and offers for her to return to the apartment in the spring if she desires, this time as a friend and not a prisoner. On the last day of the second year, Adrian looks for Linda in the mirror and sees her being dragged into a building by a man. He rushes to her rescue and is shot in the process. As he lays dying, he asks Linda for a kiss. She kisses him, breaking the spell and turns him back to normal. He explains everything to Linda and the two go back and live in the apartment together. Adrian had also made a deal with Kendra, and because of it, Will regains his sight, and Magda is allowed to return to her family. Kendra reveals that she was Magda, punished to remain a servant forever because of her careless spell but she can now return home as well.

Here is the data which can be found from the novel based on the theory of Kovecses of the types of metaphor.

\section{Structural metaphors}

This kind of metaphor is to enable speakers to understand the metaphor in the source language to the target language. Different parts of experiences that are complex but too abstract are conceptualized with the help of simple but known experiences.

\section{Data 1}

\section{SL : She was a fat chick}

\section{TL : Seorang anak perempuan yang gemuk}

It is clear to see and understand how the translation was done by the translator from the source language in English into Indonesia as the target language. The word "Chick" in the physical meaning is a young bird, and the bird symbolizes feminine. By this, we can see that the data is a structural metaphor. Furthermore, by comparing a chick and a girl we found they have almost the same characters. Generally, most girls under 17 years old are so fragile, young, and easy to cry, and interestingly some sources stated "chick" or young girl is so spoiled to anyone around her, especially the mother. On the other hand, girls or women are the ones who produce eggs in their ovaries, just like a young bird (in this case juvenile chicken).

The translator mentioned this data as the metaphor since it expressed the language which did not easy to be found literally. We have a figurative image in our mind, therefore for the reason, some people make metaphors in its usage for a social life or public consumption more often. A metaphor is sometimes further analyzed in terms of its ground and tension. The ground consists of the similarities between the tenor and the vehicle. The tension consists of the dissimilarities between the tenor and the vehicle. From the data, we found the tenor which is in SL (chick) had similarity with TL (anak perempuan).

Data 2

SL : They're sheep, following the herd

TL : Mereka adalah para domba yang mengikuti sang pengembala

Based on the data above, we able to find the structural metaphor from the component of sentences both in the source language and target language, "they are sheep" into mereka adalah domba. As we know that sheep is the animal which is very happy to be in a group and always follow the dog or herd. In the story from the novel Beastly, some girls at school always make fun of other people especially ugly people and follow one of the popular girls among the group members. It was said Sloane Hagen, a beautiful but mean girl in the story who loves the main character in the story 'Kyle Kingsbury'. Whatever Sloane will do, and to anyone that she hates then all of her group members would follow her and very obedient as if she is the herd who is followed by sheep.

From both languages in English and Indonesia has a very close connection, it gives better comprehension for the reader to understand the 
meaning from the metaphor in the data. Sheep is the word that gives the connection structurally for the girl who always follows anyone and imitates one of their friends. Based on the theory of metaphor, the data used metaphoric expression and was explaining more how the sheep could be compared with humans. The word 'sheep' motivates the use of this metaphor is as follows: In our imagination that people can be like sheep as the animal is always in a group daily life. They have some way of thinking and vision doing things and for sure the dog is the leader. Sheep are a prey species, and their only defense is to flee. It displays an intensely gregarious social instinct that allows them to bond closely to other sheep and preferentially to related flock members. Flock or group mentality movements protect individuals from predators. In the cold season country, most people choose to have farms and sheep are usual animals we could see. It is clear to see that the word 'sheep' becomes the center of the semantic motivation, and motivates the use of this metaphor, as a means of showing the characters between human and sheep that could be compared as a metaphor.

\section{Ontological metaphors}

In this type of metaphor, provides much less cognitive structuring for target concepts than structural ones do. Ontological metaphors are used for a variety of purposes, such as referring (e.g., My fears are driving me crazy), quantifying (e.g., You've got too much hostility in you), identifying aspects (e.g., His emotional health has deteriorated), identifying causes (e.g., He did it out of anger), setting goals and motivating actions (e.g., He went to New York to seek fame and fortune) (Lakoff and Johnson 1980, 26-27). Via ontological metaphors, as Kövecses $(2010,38)$ notes, new ontological status is given to general categories of abstract target concepts and undelineated experiences receive a more delineated status.

The data in this type of metaphor conceives the experiences in terms of objects, substances, and containers, in general, without specifying exactly what kind of objects, substances, or container is meant. Generally, ontological metaphors are to see a more sharply delineated structure where it is very little or none.

Data 3

SL : She stared at me, and the green parts of her eyes seemed to flash and looked like they might boil over the sides of her skinny nose.

TL : Cewek itu menatapku, dan bagian matanya yang berwarna hijau seakan-akan berkilat dan terlihat seperti hendak mendidih hingga ketepian hidung lancipnya.

The ontological metaphor occurred in the data above. Once we can conceptualize the experience into a specific object or material, we can classify, group, quantify, etc. As a result of this, we can reason about the experience. Even if the boundary of things in the objective world is not clear, we still classify them as a range of mountains, corners of the street, the row of trees, etc. Setting such boundaries is to serve the purpose of communication of humans like defining a geographical area or a location for an appointment. The word "flash" was translated by the translator into "berkilat" whether for real meaning flash means to shine or light. If we can find the metaphor in the data, so how can flash burn or boil the eyes or even the nose. The ontological metaphor can also remove some of the meaning from the lexical word into the meaning based on the figurative language. By this type of metaphor, it enables us to see a more sharply delineated structure where it is very little or none. We can perceive of personification as a form of ontological metaphor. In personification, human qualities are given to nonhuman entities.

Data 4

SL : The smell reminds me of those times. I can see them in my mind"

TL : Aroma ini mengingatkanku saat-saat itu. Aku dapat melihatnya dalam pikiranku.

The ontological conceptual metaphor like this frequently occurs in human thinking. The data above, have shown the phrase in SL 'I can see them in my mind' was translated into 'aku dapat melihatnya dalam pikiranku' in TL, which motivated the used of ontological metaphor as self-evident, direct descriptions of mental phenomena.

As we can see from the SL that we found in which we cannot see something in our mind but we can only imagine it. However, in the data TL found the translator put the word "dapat melihat" or 'can see them in mind'. This means that the ontological metaphor exists. Since the meaning of the ontological metaphor provides much less cognitive structure, the phrase 'the smell reminds me' or 'aroma ini mengingatkanku' also shown the existence of ontological that the word 'smell' is a noun which we know cannot do some actions. However, in this case, it looks like doing something to the person 'me'.

\section{Orientational metaphors}

This type of metaphor provides an even less conceptual structure for target concepts than ontological ones. It can be opposed to the structural ones in such a way that the metaphorical build the structure of one concept in terms of another, but rather organize a whole system of concepts concerning one another. The nature of orientational metaphors lays deeply in our physical structure or 
culture. In other words, orientational metaphor arises from a spatial concept (source domain) that maps onto a non-spatial concept (target domain).

\section{Data 5}

SL : Kyle..you are down with your darkness, you are beastly!

TL : Kyle..kau bersedih dengan kegelapanmu, kau buruk rupa!

In this type of metaphor, the system of ideas is organized concerning and interaction in space like up-down, inside-out, front-behind, shallow-deep, center-periphery, etc. From this data, we able to see the orientation about how was "down" can be in different meanings in the metaphor. In source, language stated that "Kyle, you are down with your darkness" the word "down" means "sad" for the metaphor conceptual meaning. In this case, the reader should know how to understand the meaning of each word in the data from the novel.

The story in this part of the sentences from the novel, Kyle was very depressed and feeling so hard to believe that he transformed into a beast, cursed by Kendra the witch. Orientational metaphors used to describe the state of being. Orientational metaphors give an abstract concept, such as an emotion, a spatial orientation (Lakoff \& Johnson, 2003). Orientational metaphors that include a description of verticality are commonly used to describe and understand emotional experiences. When someone is feeling depressed can be said "They are feeling down." Metaphors that reference verticality are not limited to emotions. Objects, feelings, and experiences that are positive are often expressed as being "up" or "high" and negative things are "down" or "low" (Meier \& Robinson, 2004). We can see the word 'come down' motivates such a figure of speech which described as having the following reasoning: after trying to find the solution for the condition of the injustice or the unfair treatment that he (Kyle) suffers from the worst thing in his life, he never finds the answer and this makes him so desperate that he cannot even stand it any longer.

\section{Data 6}

$\mathrm{SL}$ : He is in the top situation. Kyle is under Magda's control at the moment. He spoke to his mind.

TL : Ia sedang merasa bahagia. Kyle dalam pengawasan Magda saat ini. Ia berkata pada dirinya.

The phrase 'happy is up', allows us to conceptualize our emotional experiences in more sharply defined terms because of the basic physical similarities we can go one step further and clearly define and understand the abstract experiences of others. Feeling happy is like being on top or high up. It happens to Kyle or Adrian as the beast. They meet at night when they go to the living room. Their relationship then gets better as time passes. Lindy thinks of Kyle as a close friend and Kyle wishes for Lindy to see him as something more. He is in love with that girl, and the word 'top of the situation' referred to the happiest feeling of a person.

\section{Translation Quality}

In conducting and finding the result of the translation study, the researcher analyzed the questionnaire received from the raters, the researcher analyzed according to the Nababan el al (2012) about accuracy, acceptability, and readability. The example of an analysis of these aspects can be seen as below:

\section{Accuracy}

Related to the accuracy, the researcher finds two levels of this aspect consist of an accurate and less accurate level. Each level could be seen as follows:

a. Accurate

SL : She met my eyes

TL : Dia menatapku

The data above includes accurate translation. Since the message of the source language is conveyed clearly and completely. It is shown by the source language 'met my eyes' is translated into menatapku. It shows the translator did not do reduction meaning. The raters also give score 3 for this data. Thus, the data above belongs to accurate translation.

b. Less Accurate

SL : Well, your job goes bye-bye if I run away, you know that, don't you?

TL : Well, pekerjaanmu akan hilang kalau aku kabur, kamu menyadarinya kan?

The data above belongs to less accurate. Because it can be seen that there are words that are not accurately translated from the source language into the target language. It is supported by the rater who gives score 2. The sentence in the source language Well, your job goes bye-bye if I run away, you know that, don't you? translated into Well, pekerjaanmu akan hilang kalau aku kabur, kamu menyadarinya kan? in the target language. A word Well is not translated in the target language. Then, the verb phrase goes bye-bye is translated into akan hilang shown the different tense usage in the source language and target language. In the target language, there is a word akan which indicates future tense in bahasa Indonesia whereas the phrase goes bye-bye shows present tense in the source language. The source. Well, your job goes bye-bye if I run away, you know that, don't you? should be translated into Baiklah, pekerjaanmu hilang kalau aku kabur, kamu menyadarinya kan? in the target 
language. Thus, the data above includes a less accurate translation.

\section{Acceptability}

In the acceptability aspect, the researcher finds two levels of this aspect such as acceptable and less acceptable. Each level could be analyzed as follow:

\section{a. Acceptable}

SL : "What are you looking at, Ugly?"

TL : "Apa yang kau lihat, Buruk Rupa?"

The data above includes an acceptable translation. The raters also have the same opinion so that they give score 3 . The translator translated the word of the source text into a common expression in the target language therefore, it looks natural in the target language. Ugly is translated into Buruk Rupa. The translator considers the context of the text so that the word choice is applied to make it natural and acceptable in the target language. Thus, the source language Ugly is translated into Buruk Rupa in the target language belongs to acceptable translation.

b. Less Acceptable

SL : We traveled outside New York and visited witches and voodoo people too.

TL : Kami pergi ke luar kota New York dan mengunjungi para penyihir dan dukun voodoo juga.

The data above belongs to less acceptable translation. The rater gives a score of 2 . It is because translation is an unfamiliar sentence in the target language. It is proven by We traveled outside New York and visited witches and voodoo people too is translated into Kami pergi ke luar kota New York dan mengunjungi para penyihir dan dukun voodoo. This translation is a little bit difficult to be understood and accepted because of the word "people". The word people is translated into dukun which is shown that there is an emphasis on the target language that people are not a group of persons in general but special people that related to voodoo activities. In this case, the word voodoo is also not translated into bahasa Indonesia in the target language. Therefore, this noun phrase voodoo people and its translation dukun voodoo belong to less acceptable.

\section{Readability}

In aspect readability, the researcher finds two levels of this aspect such as readable and less readable. Each level could be analyzed as follows:

\section{a. Readable}

SL : "Yeah, goodness. Girls think goodness is hot."

TL : Yeah. Kebaikan, cewek-cewek memang menganggap kebaikan menggairahkan.

The translation above belongs to readable translation. It is because the translator used a common vocabulary of the target language. The source text. Yeah, goodness. Girls think goodness is hot is translated Yeah. Kebaikan, cewek-cewek memang menganggap kebaikan menggairahkan in the target language so that the reader does not feel confused in understanding the text. The word 'hot' is not translated literally into 'panas' but it uses another word 'menggairahkan' which still has a relation with the word 'hot'. It is supported by the raters that give score 3 . Thus, the data above belongs to readable translation.

\section{b. Less Readable \\ SL : Roses are cheap \\ TL: Mawar itu murahan}

The data above includes a less readable translation. It is because the target language above is difficult to understand. It is shown by Roses that are cheap and are translated into Mawar itu murahan. The word murahan makes the reader is difficult to catch the message. The reader needs to read more than once. It is why this data belongs to less readable. It is supported by the rater who gives score 2 .

Besides, this research would obtain the result from the questionnaire which was spread to some correspondents. They had an English background of education for their knowledge, to be able to comprehend well the discussion of this study. They should read the novel first, and then check the metaphor from the data source. Comparing the SL and TL, on the other hand, they must be able to know the meaning of the figurative language which appeared in the data. Translation assessment is always related to good or bad translation results. If we discuss translation as products and translation as an activity so the problem of the quality of translation has been one of the top priorities. All the translators have the same purposes that produce a good translation and a familiar target text translation that appropriate to the target culture. There are some criteria to know the translation is good or bad. However, these criteria are determined by the objective assessment and the basic theory which are applied to the quality of translation.

\section{CONCLUSION}

From the previous chapters, it can be concluded that some of the translations were done based on the undergoing theory of translation. The conclusion in this study was done according to the data from the English and Indonesian novel entitled 'Beastly'. 
Based on the foregoing analysis and discussion, the following points can be drawn as conclusions:

Based on the analysis, we found that the use of a structural metaphor was mostly used in this study based on the data in the novel Beastly. The structural metaphor occurred as the source domain provides a relatively rich knowledge structure for the target concept. In other words, this kind of metaphor is to enable speakers to understand target A using the structure of source B. Structural metaphors arise when the source domain provides a "rich knowledge structure for the target concept" [Kövecses 2010: 37]. The source-target projects easily perceived and comprehensible mappings that deliver the metaphor to the target source in a comprehensible way. From both languages in the data from the source language to target language have a very close connection and from the explanation gives better comprehension for the reader to understand the meaning of the metaphor in the data.

And for the second result, we can say in terms of quality of translation there has been general agreement on one important point. The researcher analyzes translation quality refers to Nababan "es Theory as a grand theory and found that there are accuracy, acceptability, and readability aspects. Theorists may have fervently disagreed on which is the best way to translate, literally vs. freely, or the translator being visible vs. invisible (Venuti, 1986). However, most theorists have in a sense agreed in that they have stated that, given a source text, there is just one best approach to translating it, the approach that complies with that theorist's views on how to translate. Furthermore, finding the results of quality in translation in this study was conducted through questionnaires from some correspondents. Based on the questionnaire which is focused on words, phrases, and sentences are considered good quality.

\section{ACKNOWLEDGMENT}

The authors would like to thank all of the correspondents who are willing to participate in this research. Next is the extended-expression of gratitude to some other parties for their endless support and continuous cheer.

\section{REFERENCES}

[1] Allan, Keith. 1986. Linguistic Meaning. London: Routledge and Kegan Paul plc.

[2] Basnett, Susan - Mc Guire. 1985. Translation Studies. London and New York: Methuen, Inc.

[3] Bell, R.T. 1991. Translation and Translating: Theory and Practise. London: Longman.

[4] Departemen Pendidikan Nasional. 2008. Kamus Besar Bahasa Indonesia Pusat Bahasa. Jakarta: Gramedia Pustaka Utama.

[5] Flinn, Alex. 2011. Beastly. New York: Harper Collins Publisher

[6] Flinn, Alex. 2011. Beastly. Jakarta: PT. Gramedia Pustaka Utama
[7] Hatim, Basil. 2001. Teaching and Researching Translation. England: Longman.

[8] Hornby, A.S. 2010. Oxford Advanced Learner's Dictionary $7^{\text {th }}$ Edition. Oxford: Oxford University Press.

[9] Larson, M.L. 1989. Meaning-Based Translation. A Guide to Cross-Language Equivalence. Second Edition. Lanham: University Press.

[10] Larson, Mildred L. 1998. Meaning - based Translation. America: University Press of America, Inc.

[11] Newmark, Peter. 1988. A Textbook of Translation. London: Prentice Hall International

[12] Nababan, M, Rudolf. (2008). Teori Menerjemah Bahasa Inggris.Yogyakarta: Pustaka Pelajar.

[13] Nababan et, al. (2012). Pengembangan Model Kualitas penerjemahan. Artikel Kaian Linguistik dan Sastra.Vol. 24, No. 1.

[14] Nida, E.A. and Taber. 1974. The theory and Practice of Translation. Leiden: E.J. Brill.

[15] Ortony, Andrew (ed.) 1979. Metaphor and Thought. Cambridge: Cambridge University Press.

[16] Sudrama, Ketut. 2003. Strategies For Translating into Indonesian English Metaphors in Novel 'Master of the game' by Sydney Sheldon (thesis). Denpasar : Udayana University.

[17] Vinay, Jean-Paul and Darbelnet Jean. 2000. A Methodology For Translation. In Venuti (ed.) 2000, London and New York: Routledge.

[18] Venuti, Laurence (ed.). 2000. The Translation Studies Reader. London and New York: Routledge.

[19] Naraswari, W, Siwi and Nugroho, R, Arief. (2015). Translation Procedures of Culture Bound Words Used in Visitor Guide of Jawa Tengah. Unpublished. Udinus. Semarang. Indonesia. 